\title{
OUT OF TIME
}

A vision to behold.

\section{BY ELIZABETH COUNIHAN}

Do you behold me?

Is someone sending? I'm beholding someone a long way off.

$\mathrm{Ah}$ - at last, at last, a connection! So there are other Families. I thought we were the only one left. But you are so far! Too far to help us.

My friends can't behold you. They're shaking their heads.

I know. I can see them faintly like ghosts in the firelight. But you, you are strong. A new sender?

Yes. I fell from the mountain rock six months ago when we chased the herdbeasts over the edge. I broke both legs again. I'm better now but our Mother feels it's time for me to join the thinkers. She thinks I've broken enough bones now and she knows I'm from a line of strong senders.

Surely we all have that gift or it comes to all of us in time. You're probably sorry not to run with the hunt any more but we all grow up and get injured. Then we are senders and thinkers. Isn't that what makes us different from other beasts?

No, I'm not sorry. I can always go fishing if I want to. Some of the children are teaching me to make fish hooks.

Fish hooks? Show me.

Now I understand. We don't have those. Your children must be very clever! So there is a river near you?

I can't see 'river'. What is it? Oh! Like that. No our fishing place is much bigger. It stretches as far as the eye can see. Look!

How the Moon sparkles on it! Does it go on forever or is there land on the other side?

In the daytime we can see a faraway country over there.

I wish I could see it in the flesh but I know you're too far away - many months of travel. We are so few and we will all die soon.

Are there many of you? Show me.

You send feelings of distress.

We are a strong Family. See how many.

Yes, you have more than three, maybe four times our number.

You say you need help. Some of our youngsters would be eager to try. We haven't beheld another Family for at least a year.

No, it's too far and there's ice and snow between and all manner of dangerous beasts. We're trapped here now.
Our youngsters can't behold you at this distance but show me your location and I can pass it on to them.

No, it's impossible. We are surrounded and our death is imminent. It's too late for anyone to help us in the flesh. But before I die I must try a very great sending. That's the help I need. My friends are weak from hunger and wounds and none of our great

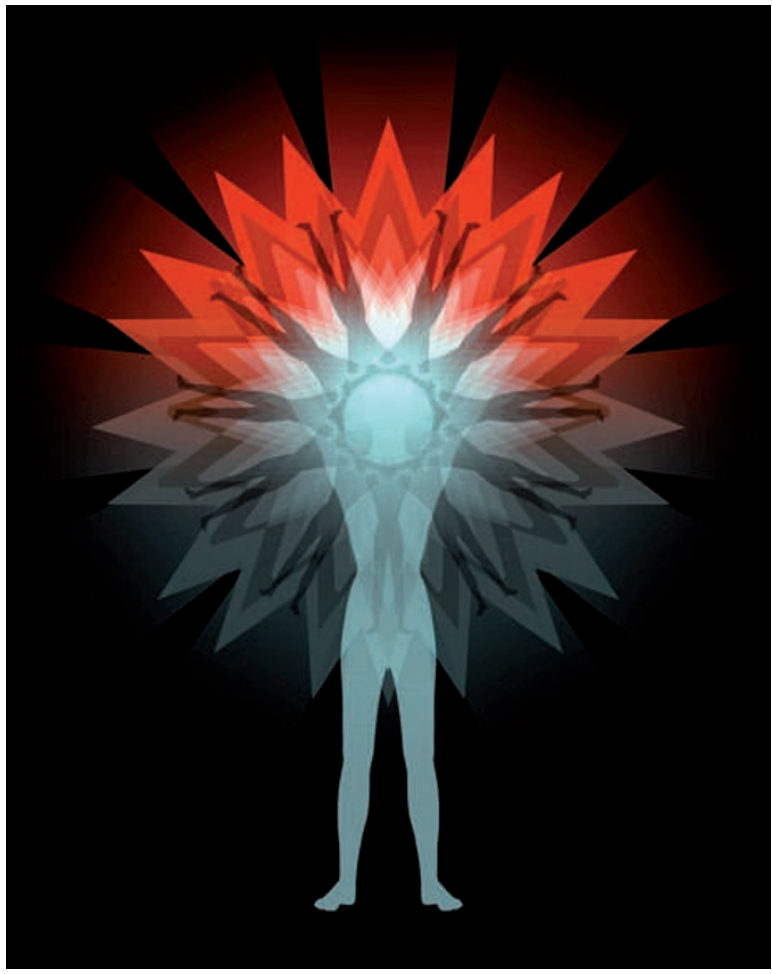

screaming children and they aren't able to behold us or each other. Therefore they are beasts, although very bold and cunning. They send raiding parties against us nearly every night. They're going to kill us all soon - tonight maybe.

Don't give up hope. How can I soothe your anguish? What do you want from me?

Are you sitting outside under the Moon? Yes.

Under the red star?

I see it.

Do you behold it?

The red star? No, of course not.

Join with me. Do you behold it now?

I... no. Wait. Very faint. A sending? That's impossible. And wonderful. Let's hold.

Yes, yes!

Hold! Your sending is losing strength.

Ah, no. They've come again. Not tonight. Let it be any other night.

You're injured! What's happened? I behold the screams of your Family! I see shapes through your eyes. Beasts attacking? No they're people - roundheaded. Terrible pain.

Beasts. I will kill them all! They're screaming at each other as they always do. That's the only way they can communicate. Mindless, sendless brutes!

No, you're wrong. They aren't beasts. They think as we do. They make wonderful and useful things. They sing and make fire.

But they are deaf and dumb! Can senders is still alive. But perhaps if I join with the greatest senders of your Family we will behold something wonderful.

I'm the only one who can behold you. I am the strongest. You are weeping. Why?

Because I think you and I must be the last of our kind.

No! We have children. I have children!

Yes, but they're not like you - some are very faint to behold. And you have no strong senders. I wonder why that is. The help I need is a sender's help before we're wiped out by the Child Beasts. There are so many near here. We fight them but they are stronger and faster than we are.

Child Beasts? Show me. Oh - you mean the Roundhead People. We have them too. But they're not beasts, they're...

They are beasts! We behold their heads full of anger and blood. They send like they behold the sender from the red star? You know. You behold! But you are a traitor! I see now why your people are as faint as ghosts. You have mingled with the roundhead ones. Your children will never know the people of the stars! But I behold you, Starman! You are like a bolt of lightning. I can feel my spirit leaving. Will it reach you at last?

Silence. Are you and all your people dead? I can't reach the starman alone and maybe never will again. That's why I'm weeping, Mother, children, all of my Family. But behold: I'll tell you what I saw.

Elizabeth Counihan has had stories published in Nature, Asimov's, Realms of Fantasy and several anthologies. She's still looking for a publisher for her children's science-fiction novel set after a future ice age. 